\title{
IMPLEMENTASI METODE RAD (RAPID APPLICATION DEVELOPMENT) PADA PROSES PENDAFTARAN DAN TEST SELEKSI PENERIMAAN MAHASISWA BARU SECARA ONLINE
}

\author{
Teuku Radillah ${ }^{1}$, Pauzun ${ }^{2}$ \\ ${ }^{1,2}$ Akademi Manajemen Informatika Dan Komputer (AMIK) Mitra Gama \\ Jl. Khayangan No 99 Kota Duri kode pos 28784 \\ e-mail :t.radillah@gmail.com
}

\begin{abstract}
ABSTRAK
Pendaftaran dan seleksi penerimaan mahasiswa baru merupakan serangkaian kegiatan yang dilakukan secara rutin pada setiap tahunnya oleh setiap perguruan tinggi. Saat ini sistem pendaftaran dan seleksi penerimaan mahasiswa baru masih dilakukan secara konvensional, yaitu calon mahasiswa harus datang kekampus dan mengisi formulir pendaftaran, kemudian melakukan ujian test seleksi menggunakan CBT (Computer Based Test). Cara seperti ini tidak efektif bagi calon mahasiswa yang berada diluar atau pingiran kota Duri, karena memerlukan biaya transportasi, serta waktu. Pada penelitian ini memberikan solusi dengan menggunakan smartphone berbasis metode (Rapid Aplication Development). Berdasarkan implementasi yang dilakukan, calon mahasiswa yang melakukan registrasi ulang berdasarkan hasil wawancara merasa sangat puas dan aplikasi ini benar-benar sangat membantu karena dapat menentukan sendiri kapan bersedia melakukan test online sesuai dengan batas akhir pendaftaran, dan hasil penerapan sistem ini menunjukan kemajuan yang signifikan pada jumlah calon mahasiswa yang mendaftar secara online terutama diluar kota Duri
\end{abstract}

Kata kunci : Pendaftaran, Seleksi Mahasiswa, Online, RAD

\begin{abstract}
Registration and selection of new student admissions are a series of activities carried out regularly every year by each university. Currently, the system of registration and selection for new admissions is still carried out conventionally, namely prospective students must come to the campus and fill in the registration form, then conduct a selection test using CBT (Computer Based Test). This method is not effective for prospective students who are outside or the outskirts of the city of Duri, because it requires transportation costs and time. This study provides a solution using a method-based smartphone (Rapid Application Development). Based on the implementation carried out, prospective students who reregister based on the results of the interview are very satisfied and this application is really very helpful because they can determine for themselves when they are willing to take an online test according to the deadline for registration, and the results of implementing this system show significant progress in number of prospective students who register online, especially outside the city of Duri
\end{abstract}

Keywords: Registration, Student Selection, Online, RAD

\section{PENDAHULUAN}

Penerimaan mahasiswa baru merupakan kegiatan rutinitas yang dilakukan oleh setiap perguruan tinggi baik perguruan tinggi swasta maupun negeri. Penerimaan mahasiswa baru tersebut biasanya dilakukan secara konvensional, yaitu mahasiswa harus datang kekampus, mengisi formulir dan menyerahkan beberapa persyaratan yang telah ditetentukan. Jika sebagaian perguruan tinggi yang telah menyediakan fasiltas 
IN F ORMA TIK

Jurnal Informatika, Manajemen dan Komputer, Vol. 12 No. 2, Desember 2020

eISSN : 2580-3042

pISSN : 1979-0694

pendaftaran secara online akan tetapi untuk ujian seleksi tetap harus datang kekampus.

Permasalahan yang sama juga dialami oleh perguruan tinggi Akademi Manajemen Informatika dan Komputer (AMIK) Mitra Gama yang memiliki calon mahasiswa yang tersebar di luar kota Duri, seperti Bagan siapi-api, Bagan Batu, Ujung Tanjung, dan perbatasan kota Duri lainnya.

Setiap siswa biasanya mendatangi kampus untuk pengambilan formulir, dan akan datang kembali untuk melakukan proses ujian seleksi, sistem pendaftaran manual seperti ini tentu saja membuat calon mahasiswa harus menyiapkan waktu, dan sangat menyulitkan bagi calon mahasiswa yang memiliki pekerjaan, dan terkadang membuat calon mahasiswa berubah pikiran untuk mencari perguruan tinggi yang lain yang memiliki fasilitas pendaftaran secara online. Untuk mengatasi permasalahan tersebut dibutuhkan suatu system pendaftaran secara online, menggunakan smartphone berbasis metode RAD (Rapid Aplication Development) yang diawali dengan tahapan requirement planning, system design, dan implementation. dan pada sistem tersebut juga dilengkapi dengan fitur ujian seleksi juga secara online, sehingga calon mahasiswa dapat melakukan pendaftaran dimana saja dan ujian dimana saja menggunakan koneksi internet.

Adapun tujuan penelitian secara global yang dilakukan adalah sebagai berikut :

a. Memberikan solusi bagi calon siswa diluar kota Duri untuk tetap mendaftar kuliah dan ujian seleksi penerimaan mahasiswa baru secara online.

b. Menciptakan sistem pendaftaran dan ujian seleksi penerimaan mahasiswa baru yang inovatif berbasis perkembangan IT saat ini.

Manfaat keilmuan dari hasil penelitian yang berjudul Implementasi Pendaftaran dan Ujian Seleksi Penerimaan Mahasiswa Baru Secara Online dengan Model Rapid Aplication Development ini adalah :

a. Memberikan kemudahan bagi manajemen perguruan tinggi khususnya AMIK Mitra Gama dalam promosi penerimaan mahasiswa baru

b. Meningkatkan kualitas layanan penerimaan mahasiswa baru dengan fitur pendaftaran dan ujian seleksi secara online.

c. Menjadi bahan refrensi pengembangan keilmuan dalam bidang pemograman yang

memiliki studi kasus serupa khususnya dilingkungan akademisi dan praktisi computer

Penerimaan mahasiswa baru (PMB) Online merupakan produk layanan aplikasi perangkat lunak yang online real time berbasis website. PMB merupakan suatu proses administrasi yang terjadi setiap tahun untuk seleksi calon siswa berdasarkan nilai akademik agar dapat melanjutkan pendidikan pada jenjang yang lebih tinggi (Zain, Sari, \& Arif, 2018). Test seleksi penerimaan mahasiswa baru secara online merupakan proses pendaftaran menggunakan sistem online, yaitu calon mahasiswa dapat mengakses pendaftaran dimanapun berada dengan adanya koneksi internet. Pendaftaran mahasiswa secara online sudah banyak diterapkan diberbagai perguruan tnggi akan tetapi hanya sebatas pendaftaran saja, sedangkan untuk ujian seleksi masih harus datang kekampus untuk melakukan ujian seleksi dengan menggunakan CBT (Computer Based Test). Pada penelitian ini untuk pendaftaran serta ujian test online sudah satu paket didalam aplikasi, yaitu calon mahasiswa dapat melakukan test atau ujian online setelah bukti pembayaran diupload, dan diverifikasi oleh bagian keuangan.

\section{a. Definisi Web}

Web merupakan resource (sumber) daya internet yang berkembang sangat pesat. Perkmbangan informasi web dilakukan dengan pendekatan hyperlink yang menjadikan suatu teks, gambar, ataupun objek menjadi kerangaka untuk membuka halaman-halaman yang lain yang saling berkaitan, sehingga memalui pendekatan ini seseorang dapat memperoleh informasi dari satu halaman ke halaman yang lain (Harison \& Syarif, 2016).

\section{b. Konsep Dasar Sistem Informasi}

Sistem adalah sekelompok komponen dan elemen yang digabungkan menjadi satu untuk mencapai tujuan tertentu. Ssistem adalah elemen yang terintegrasi untuk mencapai tujuan organisasi atau perusahaan yang terdiri atas sejumlah sumber daya. Sistem merupakan sekelompok komponen dan elemn yang saling berhubungan dan bekerjasama untuk mencapai suatu tujuan (Indrajani, 2015).

Sistem informasi adalah suatu sistem didalam suatu organisasi yang mempertemukan kebutuhan, pengolahan transaksi harian yang mendukung fungsi operasi organisasi yang bersifat manajerial dengan kegiatan strategi dari 
IN F O R M A I I A

Jurnal Informatika, Manajemen dan Komputer, Vol. 12 No. 2, Desember 2020

eISSN : 2580-3042

pISSN : 1979-0694

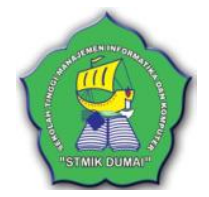

suatu organisasi untuk dapat menyediakan laporan-laporan yang diperlukan oleh pihak luar tertentu (Sutabri, 2012)

\section{c. Konsep Dasar Database}

Konsep dasar dari database adalah koleksi dari data - data yang terorganisasi sedemikian rupa sehingga data mudah disimpan dan dimanipulasi (diperbaharui, dicari, diolah, dengan perhitungan - perhitungan tertentu, serta dihapus). (Nugroho, 2011).

Menurut Indrajani (2015: 70) menyatakan bahwa basis data adalah sebuah kumpulan data yang saling berhubungan secara logis, dan merupakan sebuah penjelasan dari data tersebut, yang didesain untuk menemukan data yang dibutuhkan oleh sebuah organisasi.

Basis data (Database System) merupakan suatu sistem informasi yang mengintegrasikan kumpulan dari data yang saling berkaitan satu dengan yang lainnya (Priyadi, 2014)

\section{d. $M y S Q L$ dan $S Q L$}

$M y S Q L$ adalah sebuah program database server yang mampu menerima dan mengirim datanya dengan sangat cepat, multi user serta menggunakan perintah standar SQL (Structure Quered Language) (Nugroho, 2016). MySQL memiliki dua bentuk lisensi, yaitu FreeSoftware danShareware. MySQL yang biasa kita gunakan adalah MySQLFreeSoftware yang berada dibawah lisensi GNU/GPL (General Public License). MySQL adalah sebuah database yang dapat digunakan baik sebagai client maupun server (Wahana Komputer, 2012)

\section{e. Personal Home Page (PHP)}

PHP merupakan singkatan dari Hypertext Preprocessor yang merupakan bahasa berbentuk scripting server-side untuk pengembangan web. Script PHP merupakan sekumpulan instruksi pemograman yang diterjemahkan saat proses runtime. Oleh sebab itu, PHP dapat melakukan apa saja yang bisa dilakukan program $C G I$ lain, yaitu mengolah data dengan tipe apapun, menciptakan halaman web yang dinamis,serta menerima dan menciptakan cookies, dan bahkan PHP bisa melakukan lebih dari itu (Harison, Syarif, 2016). PHP (Hypertext Preprocessor) atau Personal Home Page merupakan secara umum dikenal sebagai bahasa pemograman script yang membuat dokumen HTML secara on the fly yang dieksekusi diserver web (Sidik, 2014)

PHP (Hypertext Preprocessor) yaitu bahasa pemrograman web server-side yang bersifat open source. PHP merupakan script yang terintegrasi dengan HTML dan berada pada server (server side HTML embedded scripting)". PHP adalah script yang digunakan untuk membuat halaman website yang dinamis. (Zain et al., 2018).

\section{f. Definisi CSS (Cascading Style Sheet)}

CSS atau Cascading Style Sheets adalah sebuah dokumen yang berisi aturan yang digunakan untuk memisahkan isi dengan layout. CSS digunakan untuk mengatur tampilan dokumen HTML, contohnya seperti pengaturan jarak antar baris, teks, warna, dan format border bahkan penampilan file gambar (Rajak \& ., 2016)

\section{g. Definisi Bootstrap}

Boostrap adalah kerangka font-end yang berfungsi untuk pengembangan responsive web (Zakir, 2016). Dalam merancang bangun responsive web layout ada beberapa hal yang harus diketahui didalam penggunaan Framewok Bootstrap yaitu:

1. Mobile first approach

Framework bootstrap fokus utama terhadap pendekatan layout berbasis ponsel.

2. Browser support

Bootstrap didukung oleh semua browser populer seperti Firefox, Google Chrome, Internet Explorer, Opera, Safari dan browser-browser lainnya.

3. Knowledge to get started

HTML dan CSS merupakan pengetahuan dasar yang harus dimiliki agar dapat menggunakan Framework Bootstrap.

4. Responsive desain

Bootstraps responsive CSS yang dibangun dapat menyesuaikan tampilan layar desktop, tablet dan mobiles

\section{METODOLOGI PENELITIAN}

Metodologi untuk pengembangan sistem merupakan proses standard yang digunakan team pengembang untuk menghubungkan semua langkah yang diperlukan untuk menganalisa, merancang, mengimplementasi, dan memelihara sistem informasi. Adapun metodologi yang sampai saat ini masih sesuai untuk menjadi pedoman dalam pengembangan sistem adalah RAD (Rapid Aplication Development).

\section{a. Rapid Aplication Development (RAD)}

Menurut (McLeod, 2002) bahwa Rapid Application Development (RAD) adalah strategi siklus hidup yang ditujukan untuk menyediakan pengembangan yang jauh lebih cepat dan 
IN F O R M A I I A

Jurnal Informatika, Manajemen dan Komputer, Vol. 12 No. 2, Desember 2020

eISSN : 2580-3042

pISSN : 1979-0694

mendapatkan hasil dengan kualitas yang lebih baik dibandingkan dengan hasil yang dicapai.

RAD menggunakan metode iteratif (berulang) dalam mengembangkan sistem dimana working model (model bekerja) sistem dikonstruksikan di awal tahap pengembangan dengan tujuan menetapkan (requirement) kebutuhan (Zain et al., 2018).

Proses Desain Sistem (Design System): Pada tahap ini keaktifan user yang terlibat menentukan untuk mencapai tujuan karena pada proses ini melakukan proses desain dan melakukan perbaikan-perbaikan apabila masih terdapat ketidaksesuaian desain antara user dan analyst. Seorang user dapat langsung memberikan komentar apabila terdapat ketidaksesuaian pada desain, merancang sistem dengan mengacu pada dokumentasi kebutuhan user yang dibuat pada tahap sebelumnya. Keluaran dari tahapan ini adalah spesifikasi software yang meliputi organisasi sistem secara umum, struktur data dan yang lain.

- Pada tahap ini user biasa memberikan tanggapan akan sistem yang sudah dibuat serta mendapat persetujuan mengenai sistem tersebut. Beberapa Tahapan RAD terdiri dari 3 tahap yang terstruktur dan saling bergantung disetiap tahap, yaitu :

\section{1) Requirements Planning}

a) Pengguna dan analisis bertemu untuk mengidenfifikasi tujuan dari aplikasi atau sistem

b) Berorientasi pada pemecahan masalah bisnis.

2) Design Workshop.

a) Fase desain dan penyempurnaan.

b) Kelompok pendukung keputusan sistem untuk membantu pengguna setuju pada desain.

c) Programmer dan analis membangun dan menunjukkan tampilan desin secara visual dan alur kerja pengguna

d) User menanggapi prototipe kerja secara aktual.

e) Analis menyempurnakan modul dirancang berdasarkan tanggapan pengguna.

3) Implementation.

a) Sebagai sistem yang baru dibangun, sistem baru atau parsial diuji dan diperkenalkan kepada organisasi.

b) Ketika membuat sistem baru, tidak perlu untuk menjalankan sistem yang lama secara parallel

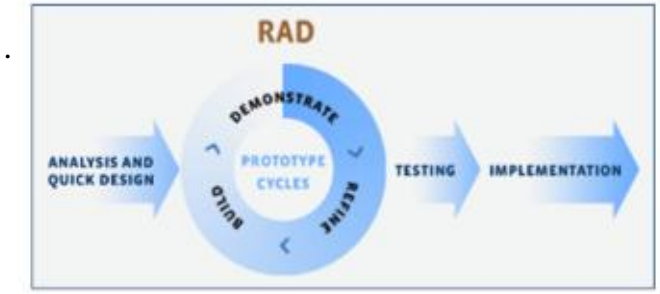

Gambar 1 Metode RAD (Rapid Aplication Development)

Sumber : Riyanto, 2017

\section{HASIL DAN PEMBAHASAN}

a. Hasil Analisa Proses

Untuk membangun suatu sistem pendafataran dan seleksi mahasiswa baru secara online dibutuhkan suatu analisa yang berkaitan dengan dengan rencana kebutuhan seperti interaksi pengguna sistem dan pengelola data mahasiswa baru serta tujuan dari sistem ini dibangun, dan untuk akses penggunakan aplikasi tersebut dapat dilihat pda Gambar 2. Use Case Diagram Pendaftaran dan Test Seleksi Penerimaan Mahasiswa Baru Secara online

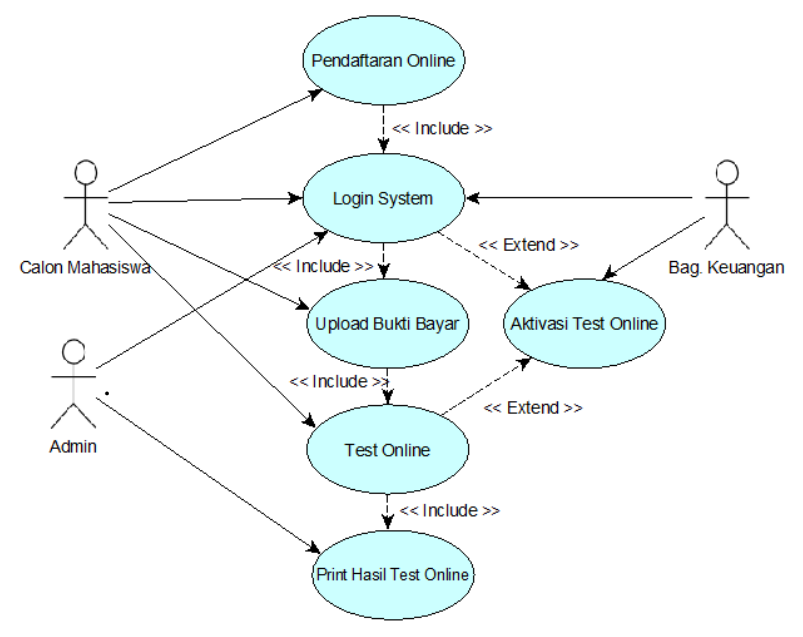

Gambar 2. Use Case Diagram Pendaftaran dan Test Seleksi Penerimaan Mahasiswa Baru

Secara online

\section{b. Gambaran Proses Pendaftaran dan Test Seleksi Penerimaan Mahasiswa Baru}

Untuk melakukan pendaftaran dan test seleksi penerimaan mahasiswa baru, calon mahasiswa terlebih dahulu melakukan registrasi pada aplikasi, berikut gambaran proses pendaftaran dan test seleksi online tersebut dapat dilihat pada Gambar 2 
IN F ORMA T I K A

Jurnal Informatika, Manajemen dan Komputer, Vol. 12 No. 2, Desember 2020

eISSN : 2580-3042

pISSN : 1979-0694

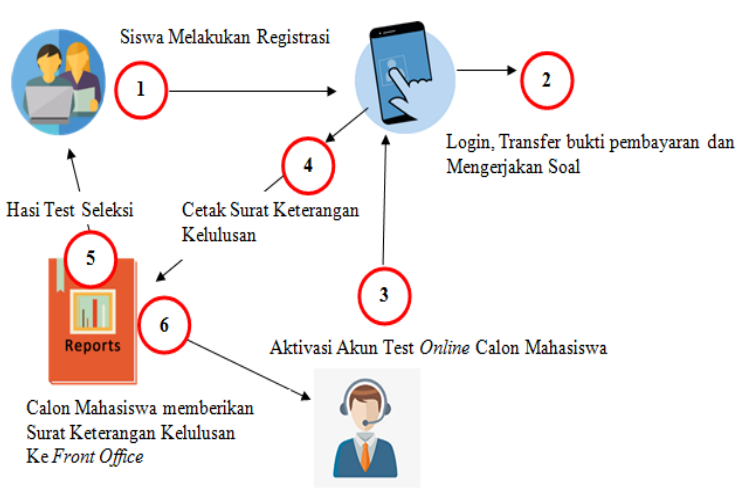

Gambar 3. Proses Pendaftaran dan Test Seleksi Penerimaan Mahasiswa Baru

\section{c. Hasil Implementasi}

Implementasi merupakan proses kelanjutan dari kegiatan perancangan system dan merupakan usaha untuk mewujudkan system yang dirancang. Langkah - langkah dari proses implementasi adalah urutan dari kegiatan awal sampai kegiatan akhir yang dilakukan dalam mewujudkan sistem yang dirancang. Untuk mewujudkan sistem tersebut dibutuhkan dukungan komponenkomponen dalam implementasi terhadap sistem yang digunakan, seperti kebutuhan komponen hardware dan software. Adapun hasil implementasi aplikasi pendaftaran dan test seleksi penerimaan mahasiswa baru sebagai berikut :

1. Untuk informasi biaya, brosur, dan cara pendaftaran serta dapat dilihat pada menu informasi pendaftaran.

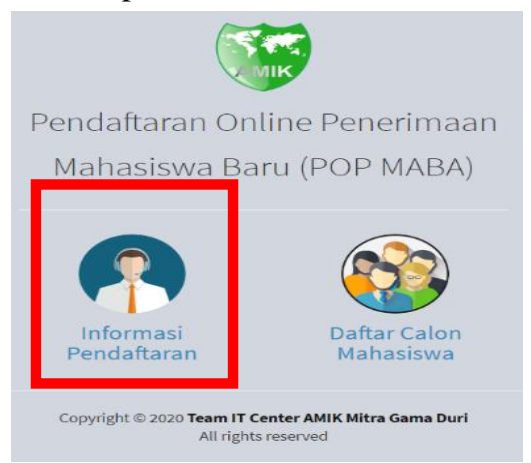

Gambar 4. Informasi Pendaftaran

Pada aplikasi POP MABA (Pendafataran Online Penerimaan Mahasiswa Baru) dengan melakukan klik icon informasi pendaftaran

3. Dashboard Calon Mahasiswa

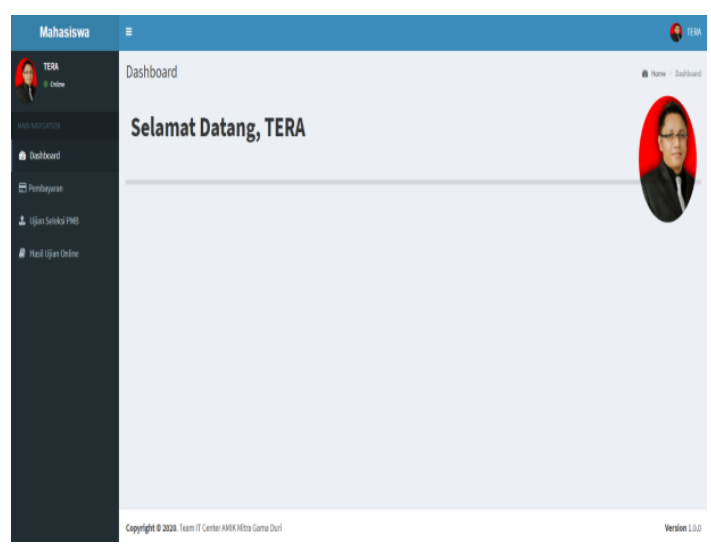

Gambar 5. Dashboard Calon Mahasiswa

Pada halaman / dashboard calon mahasiswa terdiri dari sub menu yang ada pada side bar disamping kiri, yaitu : sub menu Soal pembayaran, Ujian Seleksi PMB, Hasil Ujian Online

4. Sistem Pembayaran

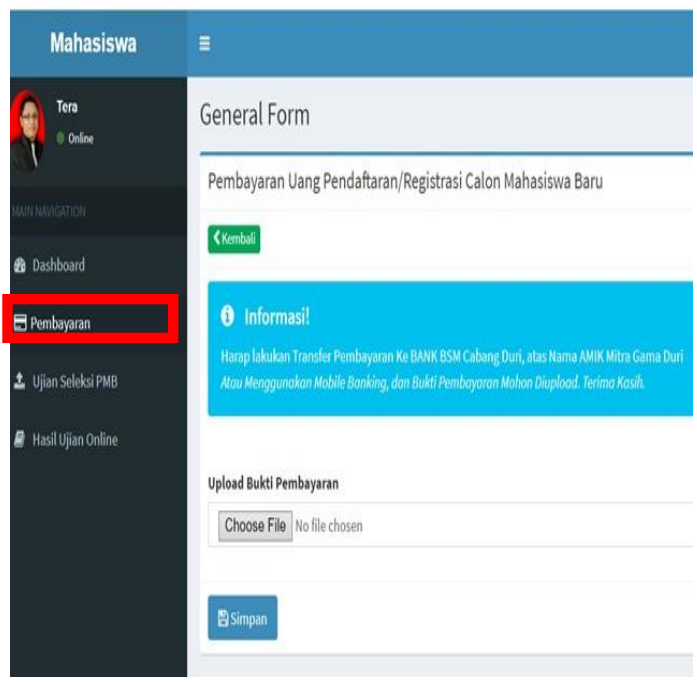

Gambar 6. Tampilan Sistem Pembayaran

Pada halaman system pemabayaran, calon mahaiswa dapat mengupload bukti transfer, dan akan secara otomatis notifikasi konfirmasi dikirim ke bagian keuangan untuk pengaktifan akun ujian seleksi penerimaan mahasiswa baru 
IN F ORMA T I K A

Jurnal Informatika, Manajemen dan Komputer, Vol. 12 No. 2, Desember 2020

eISSN : 2580-3042

pISSN : 1979-0694

5. Test/ Ujian Online

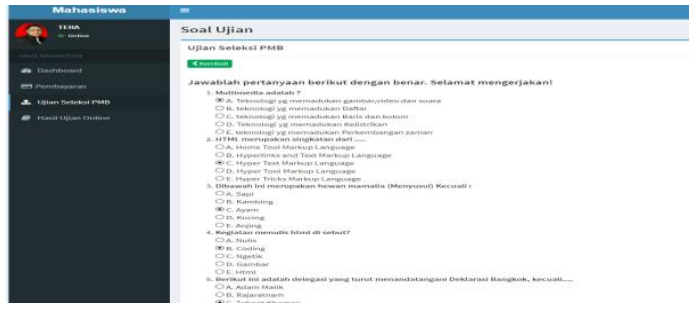

Gambar 7. Soal Test Ujian Online

6. Surat Keterangan Lulus

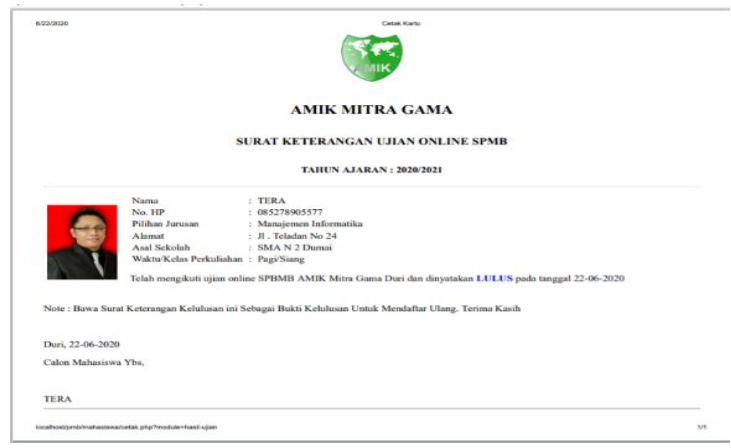

Gambar 8. Surat Keterangan Lulus

Pada halaman surat keteranga lulus merupakan hasil dari ujian yang dilaksanakan, dan sebagai bukti sah untuk melakukan pendaftaran ulang dengan membayar uang kuliah seperti tampilan Gambar 9

\section{KESIMPULAN}

Dari uraian tersebut yang telah dibahas sebelumnya dapat ditarik kesimpulan sebagai berikut :

1. Berdasarkan implementasi yang dilakukan menunjukan kemajuan yang signifikan pada jumlah calon mahasiswa yang mendaftar secara online terutama diluar kota Duri.

2. Calon mahasiswa dapat menentukan sendiri kapan bersedia melakukan test online berdasarkan batas gelombang pendaftaran yang telah ditentukan oleh pihak kampus.

3. Hasil wawancara dari calon mahasiswa yang melakukan registrasi ulang saat melakukan pembayaran uang semster merasa sangat puas dengan adanya layanan pendaftaran dan seleksi secara online ini, bagi mereka aplikasi ini benar-benar sangat membantu.

\section{REFERENSI}

Harison, \& Syarif, A. (2016). Sistem Informasi Geografis Sarana Pada Kabupaten Pasaman Barat. Jurnal TEKNOIF.

Indrajani. (2015). Database Systems All in One Theory, Practice, and Case Study. Database Systems All in One Theory, Practice, and Case Study. https://doi.org/718051154

Nugroho, A. (2011). Perancangan Dan Implementasi Sistem Basis Data. (CV. Andi Offset, Ed.). CV. Andi Offset.

Priyadi, Y. (2014). Kolaborasi SQL \& ERD Dalam Implementasi Database. (CV. Andi Offset, Ed.). Yogyakarta: CV. Andi Offset.

Rajak, R., \& . M. (2016). PERANCANGAN SISTEM INFORMASI PROFIL SEKOLAH BERBASIS WEB PADA SMA 3 KOTA TERNATE. IJIS - Indonesian Journal On Information System. https://doi.org/10.36549/ijis.v1i2.15

Sidik, B. (2014). Pemrograman Web dengan PHP : Edisi Revisi Kedua. Pemograman.

Sutabri, T. (2012). Konsep Sistem Informasi. Jurnal Administrasi Pendidikan UPI.

Wahana Komputer. (2012). SQL Server 2012. (CV. Andi Offset, Ed.). Yogyakarta: CV. Andi Offset.

Zain, S. A., Sari, E. M., \& Arif, M. (2018). Pengembangan Sistem Informasi Penerimaan Siswa Baru Berbasis Web Di Sma 1 Annuqayah Sumenep. Journal of Informatics EducationInformastics Education. 